\title{
Tinjauan Pustaka: Teknik Pengujian Toksisitas Teratogenik pada Obat Herbal
}

\author{
Tri Mulyani ${ }^{1}$, Cinta Ida Julianti ${ }^{1}$, Rikkit Sihombing ${ }^{1}$ \\ ${ }^{1}$ Program Studi Magister Farmasi Universitas Pancasila \\ Jalan Srengseng Sawah Jakarta Selatan \\ *E-mail: rikekitsihombing@gmail.com
}

Riwayat artikel: Dikirim: 03/02/2020; Diterima: 10/06/2020, Diterbitkan: 25/06/2020

\begin{abstract}
Toxicity testing of natural ingredients used in raw materials for making herbal medicines needs to be done to ensure its safety. In general, toxicity tests are divided into 2 types namely general toxicity and specific toxicity. One specific toxicity test is the teratogenic test. Teratogenic testing is part of a special toxicity test that is intended to determine the toxic effect of a compound on the fetus or fetus. The writing of this journal aims to explain the teratogenic toxicity testing technique by referring to the Organization for Economic Co-operation and Development (OECD) 414 and OECD 236 on herbal medicines. Some examples of herbs used for testing teratogenic toxicity as studied by Lu E. The et al. On Bougainvillea glabra (Paper Flower) with the results of a study of water extracts in purple and dark pink, B. glabra bract is not toxic to embryos, except the pink type with LC $5085.51 \mu \mathrm{g} / \mathrm{mL}$. then there is Mindi leaf (Melia azedarach L) which was investigated by Adisti erlina sutomo et al with the results of extracting at a dose of $3.22 \mathrm{mg} / \mathrm{kg}$ bw already causing teratogenic toxicity. And there are still some herbs that are used for teratogenic toxicity testing with mixed results.
\end{abstract}

Keywords: Teratogenic toxicity, OECD 414, OECD 236. Herbal medicine.

\section{ABSTRAK}

Pengujian toksisitas pada bahan alam yang digunakan dalam bahan baku pembuatan obat herbal perlu dilakukan untuk memastikan keamanannya. Secara umum, Uji toksisitas dibagi menjadi 2 jenis yaitu toksisitas umum dan toksisitas khusus. Salah satu uji toksisitas khusus yaitu uji teratogenik. Uji teratogenik merupakan bagian dari uji toksisitas khusus yang ditujukkan untuk mengetahui efek toksik suatu senyawa terhadap fetus atau janin. Penulisan jurnal ini bertujuan untuk menjelaskan teknik pengujian toksisitas teratogenik dengan mengacu pada Organization for Economic Co-operation and Development (OECD) 414 dan OECD 236 pada obat herbal. Beberapa contoh herbal yang digunakan untuk pengujian toksisitas teratogenik seperti yang diteliti oleh Lu E. The dkk pada Bougainvillea glabra (Paper Flower) dengan hasil penelitian ekstrak air berwarna ungu dan merah muda gelap, B. glabra bract tidak beracun bagi embrio, kecuali jenis merah muda dengan LC 50 85,51 $\mu \mathrm{g} / \mathrm{mL}$. selanjutnya ada daun Mindi (Melia azedarach L) yang diteliti oleh Adisti erlina sutomo dkk dengan hasil pemberian ekstrak pada dosis $3,22 \mathrm{mg} / \mathrm{kg}$ bb sudah menyebabkan toksisitas teratogenik. Dan masih ada beberapa herbal yang digunakan untuk pengujian toksisitas teratogenik dengan hasil yang beragam.

Kata Kunci : Toksisitas teratogenik, OECD 414, OECD 236. Obat Herbal.

\section{PENDAHULUAN}

Pengobatan dengan menggunakan obat herbal telah lama digunakan oleh masyarakat Indonesia yang secara empiris bermanfaat untuk membantu menyembuhkan penyakit. Pengembangan penelitian mengenai obat herbal saat ini semakin berkembang dan meningkat. Banyak penelitian yang dilakukan dalam upaya mengembangkan atau memanfaatkan sumber daya alam Indonesia sebagai bahan baku dalam pengembangan obat herbal. Namun, hingga saat ini hanya beberapa penelitian obat herbal yang dapat digunakan dalam fasilitas kesehatan, karena harus memenuhi persyaratan keamanan, serta manfaat dan terstandarisasi. Hal yang sangat penting yang harus dilakukan pada saat menggunakan bahan alam sebagai bahan baku obat adalah mengetahui efek toksisitas dari senyawa yang terkandung. Oleh karena itu harus dilakukan pengujian toksisitas untuk memperkirakan derajat kerusakan yang diakibatkan suatu senyawa terhadap material biologik maupun nonbiologik. Pengujian toksisitas 
DOI : https://doi.org/10.24843/JFU.2020.v09.i01.p05

pISSN: 2301-7716; eISSN: 2622-4607

Jurnal Farmasi Udayana, Vol 9, No 1, Tahun 2020, 31-36

biasanya dilakukan pada suatu calon produk untuk memenuhi persyaratan edar dan perizinan dari suatu wilayah atau negara. Hal tersebut dilakukan guna untuk menjamin keamanan penggunaan produk obat herbal terhadap konsumen. Pengujian toksisitas pada obat herbal dibagi menjadi dua, yaitu uji toksisitas umum dan khusus. Salah satu pengujian toksisitas khusus yang dilakukan yaitu uji toksisitas teratogenik.

Teratogenik merupakan perubahan formasi dari sel, jaringan, dan organ yang dihasilkan dari perubahan fisiologi dan biokimia. Teratogenik disebabkan oleh adanya teratogen. Teratogen adalah zat atau apapun (obat, zat kimia, polutan, virus, fisik) yang dalam kehamilan dapat menyebabkan perubahan bentuk atau fungsi organ dalam perkembangan janin. Senyawa teratogen akan berefek teratogenik pada suatu organisme, bila diberikan pada saat organogenesis. Faktorfaktor penyebab teratogen diantaranya adalah Faktor genetis (mutasi dan aberasi) faktor lingkungan (Infeksi, Penggunaan obat-obatan, Radiasi, Defisiensi vitamin atau hormon. Terdapat sejumlah bahan yang bersifat teratogenik pada kehidupan manusia dan hewan, antara lain, Radiasi ion (senjata atom, radioidine, dan terapi radiasi), Infeksi cytomegalovirus, virus herpes, parvovirus B-19, virus rubella, syphilis dan toksoplasmosis. Ketidakseimbangan metabolisme, misalnya karena konsumsi alkohol selama kehamilan, kretinisme endemic, defisiensi asam folat. Selain itu juga Komponen kimia obat dan lingkungan. ${ }^{13}$

Penggunaan obat pada wanita hamil dapat menimbulkan masalah tidak hanya pada ibu, namun juga pada janin. Sekitar 50\% ibu hamil dan menyusui menggunakan obat-obatan atau produk herbal yang sering dikonsumsi pada trimester pertama kehamilan. Frekuensi pemakaian obatobatan atau produk herbal yang berulang dapat menyebabkan akumulasi pada janin, sementara janin belum mempunyai sistem metabolisme yang berfungsi secara sempurna. Senyawa kimia atau zat aktif obat dapat masuk ke dalam peredaran darah janin dan mempengaruhi proses pembentukan organ pada janin sehingga dapat berefek teratogen. Sebagai contoh penggunaan obat yang berefek teratogen adalah thalidomid. Pada kasus thalidomid, ada sekitar 8000 wanita di seluruh dunia yang mengkonsumsi thalidomid yang melahirkan bayi dengan gangguan perkembangan anggota badan (phocomelia). Penggunaan obat herbal pada wanita hamil tidak menutup kemungkinan menyebabkan teratogenik pada janin. Karena didalam obat herbal juga mengandung senyawa-senyawa kimia yang berpotensi sebagai teratogen jika digunakan pada dosis tertentu. Oleh karena itu perlu dilakukannya pengujian teratogenik terhadap obat herbal yang akan dipasarkan.

Menurut perka BPOM No.7 tahun 2014 menyebutkan bahwa uji teratogenisitas merupakan suatu pengujian untuk memperoleh informasi adanya abnormalitas fetus yang terjadi karena pemberian sediaan uji selama masa pembentukan organ fetus (masa organogenesis). Informasi tersebut meliputi abnormalitas bagian luar fetus (morfologi), jaringan lunak serta kerangka fetus. Prinsip uji teratogenisitas adalah pemberian sediaan uji dalam beberapa tingkat dosis pada beberapa kelompok hewan bunting selama paling sedikit masa organogenesis dari kebuntingan, satu dosis per kelompok. Satu hari sebelum waktu melahirkan induk dibedah, uterus diambil dan dilakukan evaluasi terhadap fetus. (BPOM, 2014)

Pengujian toksisitas biasanya mengacu pada The OECD (Organization for Economic Co-operation and Developmen) Guidelines for the Testing of Chemicals yang merupakan standar yang diterima secara internasional untuk menguji keamanan produk, meliputi bahan kimiawi, pestisida, perawatan dan lain-lain. Standar ini selalu ditinjau oleh banyak pakar dari berbagai negara yang termasuk anggota OECD. Metode ini dianggap cukup ideal karena menggunakan sedikit hewan coba, mudah aplikasinya dan dapat sekaligus memperkirakan nilai LD 50. Pengujian teratogenik sendiri menurut OECD terdapat 2 metode uji yaitu sesuai dengan OECD 414 dan OECD 236. (OECD, 2018)

\section{METODE PENELITIAN TEKNIK OECD 414}

Metode uji toksisitas teratogenik sesuai dengan OECD 414 adalah pengujian secara in vivo. Uji toksisitas teratogenik dengan metode ini menggunakan spesies hewan rodent dan non rodent. Jenis hewan rodent yang disukai adalah 
DOI : https://doi.org/10.24843/JFU.2020.v09.i01.p05

pISSN: 2301-7716; eISSN: 2622-4607

Jurnal Farmasi Udayana, Vol 9, No 1, Tahun 2020, 31-36

tikus dan spesies non-rodentyang disukai adalah kelinci. Justifikasi harus diberikan jika menggunakan spesies lain. Setiap kelompok uji dan kontrol harus mengandung jumlah hewan betina sekitar 20 ekor.

Prinsip pengujian dengan metode ini adalah bahan uji diberikan pada hewan bunting setidaknya dari masa implantasi hingga satu hari sebelum jadwal pembunuhan secara manusiawi. Pedoman ini ditujukan untuk memeriksa pada periode organogenesis, (misalnya hari ke 5-15 pada hewan pengerat, dan hari ke 6-18 pada kelinci) dan juga untuk mengamati efek dari praimplantasi, melalui seluruh periode kehamilan sampai hari dilakukannya pembedahan (operasi caesar). Untuk pengamatan, betina dibunuh secara manusiawi, kandungan uterus diperiksa, dan janin dievaluasi untuk perubahan jaringan lunak dan kerangka. Prosedur pengujian toksisitas teratogenik sesuai metode ini dapat dilihat pada bagan 1 .

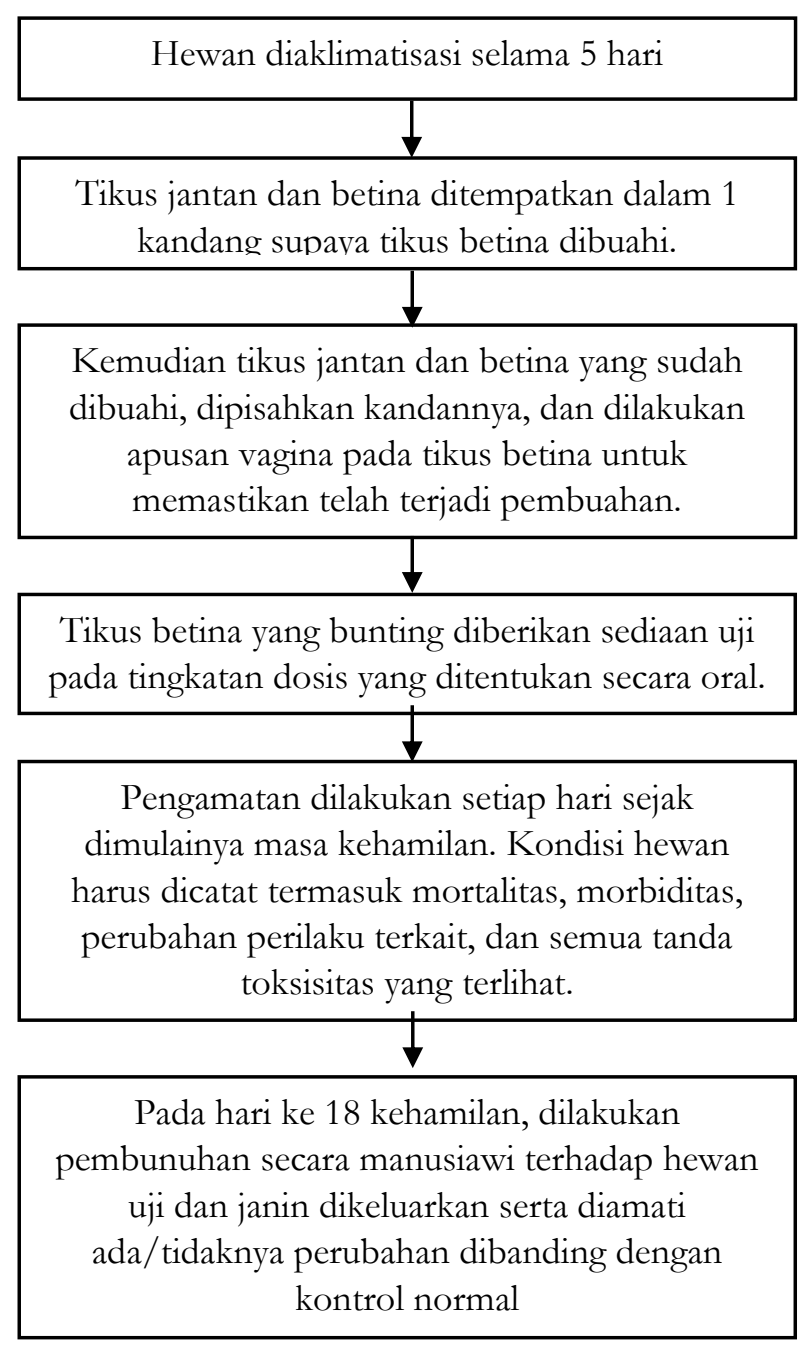

Bagan 1. Cara kerja uji teratogenik berdasarkan OECD 414
Semua data pengujiaan dirangkum dalam bentuk tabel, yang menunjukkan setiap kelompok uji, jumlah hewan pada awal pengujian, jumlah hewan yang ditemukan mati selama pengujian atau dibunuh untuk alasan manusiawi, waktu kematian atau pembunuhan manusiawi, jumlah betina hamil, jumlah hewan yang menunjukkan tandatanda toksisitas, deskripsi tanda-tanda toksisitas yang diamati (termasuk waktu onset, durasi dan tingkat keparahan efek toksik), jenis perubahan histopatologis (kelenjar tiroid), jenis pengamatan janin dan semua data disajikan secara relevan. Hasil pengamatan/ nilai LD 50 dihitung dengan meggunakan metode statistik yang sesuai. Nilai LD 50 dilihat pada saat dosis tertentu yang menyebabkan/menimbulkan gejala-gejala toksisitas teratogenik secara minimal.

\section{TEKNIK OECD 236}

Pengujian toksisitas teratogenik yang digunakan pada OECD 236 ini adalah secara in vitro menggunakan telur ikan zebra. Pengujian ini menggunakan embrio ikan zebra sebagai pengamatan terhadap toksisitas pada janin oleh paparan sediaan uji. Ikan zebra merupakan salah satu model hewan coba untuk uji toksisitas herbal. Keuntungan menggunakan ikan zebra karena hampir 82\% sekuen DNA berhubungan dengan gen manusia. Embrio ikan zebra dapat digunakan sebagai model penelitian toksisitas zat kimia, hal ini berkaitan dengan proses embriogenesis yang cepat dan memiliki struktur tubuh yang transparan, mudah dipelihara dan mewakili data in vivo pada manusia.Ukuran ikan zebra kecil, mudah beradaptasi dengan lingkungan, menghasilkan telur dalam jumlah banyak.

Jumlah embrio yang digunakan sebanyak 20 embrio per konsentrasi (satu embrio per sumur) yang dipapar dengan bahan uji. Telur ikan zebra yang baru dibuahi ditetesi dengan sediaan uji selama 96 jam. Setiap 24 jam dilakukan pengamatan yang meliputi :pembekuan telur yang telah dibuahi, kurangnya pembentukan somit, kurangnya pelepasan tail-bud dari kantung kuning telur, dan kurangnya detak jantung. Prosedur pengujian toksisitas teratogenik dapat dilihat pada bagan 2 . 
DOI : https://doi.org/10.24843/JFU.2020.v09.i01.p05

pISSN: 2301-7716; eISSN: 2622-4607

Jurnal Farmasi Udayana, Vol 9, No 1, Tahun 2020, 31-36

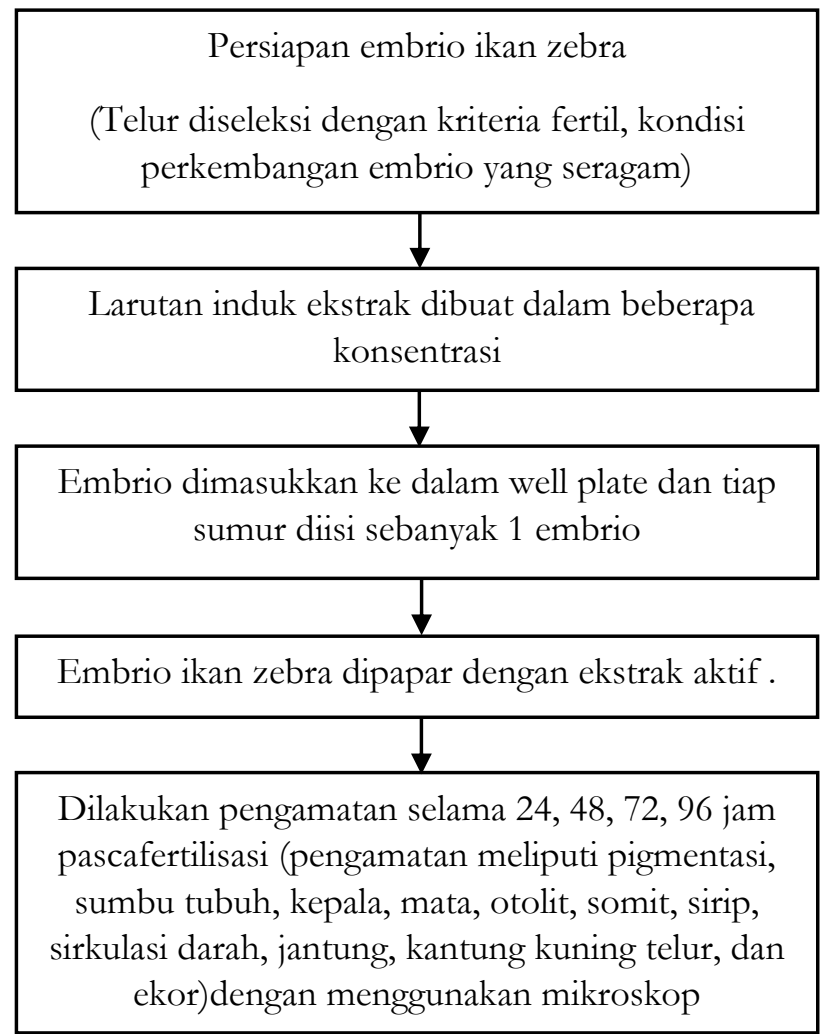

Bagan 2. Cara kerja pengujian toksisias teratogenik berdasarkan OECD 236

Pada akhir periode pajanan, toksisitas akut ditentukan berdasarkan hasil positif pada salah satu dari empat indikator pengamatan diatas, dan LC50 dihitung. Agar hasil pengujian dinyatakan valid, kriteria berikut ini berlaku:

1. Tingkat pembuahan keseluruhan dari semua telur yang dikumpulkan harus $\geq 70 \%$ dalam kelompok yang diuji.

2. Suhu air harus dijaga pada $26 \pm 1^{\circ} \mathrm{C}$ di ruang uji setiap saat selama pengujian.

3. Kelangsungan hidup keseluruhan embrio dalam kontrol negatif (air encer), dan, jika relevan, dalam kontrol pelarut harus $\geq 90 \%$ sampai akhir paparan 96 jam.

4. Paparan terhadap kontrol positif (mis., 4,0 mg / L 3,4-dikloroanilin untuk ikan zebra) harus menghasilkan mortalitas minimum 30\% pada akhir paparan 96 jam.
5. Tingkat penetasan dalam kontrol negatif (dan kontrol pelarut jika sesuai) harus $\geq 80 \%$ pada akhir paparan 96 jam.

6. Pada akhir paparan 96 jam, konsentrasi oksigen terlarut dalam kontrol negatif dan konsentrasi uji tertinggi harus $\geq 80 \%$ dari saturasi.

\section{Penentuan LC 50}

Dalam uji ini, masing-masing sumur dianggap sebagai ulangan independen untuk analisis statistik. Persentase embrio yang setidaknya satu dari indikator pengamatan menunjukkan positif pada 48 atau 96 jam diplot terhadap konsentrasi uji. Untuk perhitungan kemiringan kurva nilai LC50 dan batas kepercayaan (95\%), menggunkan metode statistik yang sesuai.

\section{HASIL DAN PEMBAHASAN}

Dari beberapa jurnal penelitian mengenai pengujian toksisitas teratogenik pada bahan alam, maka didapatkan beberapa jenis tanaman yang digunakan sebagai obat memiliki efef toksisitas teratogenik pada fetus hewan uji mencit, serta menunjukkan perubahan pada embrio zebrafish. Jenis tanaman serta hasil uji toksisitas teratogenik sesuai dengan OECD 414 dan OECD 236 dapat dilihat pada Tabel 1

\section{KESIMPULAN}

Uji toksisitas teratogenik pada obat herbal perlu dilakukan untuk menjamin keamanan produk selama pemakaian khususnya untuk wanita hamil untuk mengetahui pengaruhnya terhadap janin. Uji toksisitas teratogenik dapat dilakukan melalui 2 metode yaitu secara in vivo menggunakan hewan uji sesuai dengan OECD 414 dan pengujian secara in vitro menggunakan embrio ikan zebra sesuai dengan OECD 236. 
DOI : https://doi.org/10.24843/JFU.2020.v09.i01.p05

pISSN: 2301-7716; eISSN: 2622-4607

Jurnal Farmasi Udayana, Vol 9, No 1, Tahun 2020, 31-36

Tabel 1. Toksisitas Teratogenik Beberapa Bahan Alam

\begin{tabular}{|c|c|c|c|c|}
\hline No. & Nama Tanaman & Metode & Peneliti & Kesimpulan \\
\hline 1. & $\begin{array}{l}\text { Bougainvillea glabra } \\
\text { (Paper Flower) }\end{array}$ & $\begin{array}{l}\text { OECD } \\
236\end{array}$ & $\begin{array}{l}\text { Lu E. Teh, Chin Siang } \\
\text { Kue, Chean Hui Ng, } \\
\text { Beng Fye Lau }\end{array}$ & $\begin{array}{l}\text { Ekstrak air berwarna ungu dan merah } \\
\text { muda gelap } B \text {. glabra tidak beracun bagi } \\
\text { embrio, kecuali jenis merah muda dengan } \\
\text { LC } 5085,51 \mu \mathrm{g} / \mathrm{mL} \text {. }\end{array}$ \\
\hline 2. & $\begin{array}{l}\text { Daun Pulutan (Urena } \\
\text { lobata L.) }\end{array}$ & $\begin{array}{l}\text { OECD } \\
236\end{array}$ & $\begin{array}{l}\text { Rifngatun Nadhiroh*, } \\
\text { Diah Andriana**, Yudi } \\
\text { Purnomo** }\end{array}$ & $\begin{array}{l}\text { Pemberian dekokta daun pulutan (Urena } \\
\text { lobata L.) pada dosis MATC (Maximum } \\
\text { Allowable Toxicant Concentration) dan LC } 50 \\
\text { menimbulkan malformasi somite embrio } \\
\text { ikan zebra. }\end{array}$ \\
\hline 3. & $\begin{array}{l}\text { Rimpang Curcuma } \\
\text { longa }\end{array}$ & $\begin{array}{l}\text { OECD } \\
236\end{array}$ & $\begin{array}{l}\text { Akinola Adekoya } \\
\text { Alafiatayo , Kok- } \\
\text { SongLai, } \\
\text { Syahida, Ahmad } \\
\text { Mahmood, and Noor } \\
\text { Azmi Shaharuddin }\end{array}$ & $\begin{array}{l}\text { Efek toksisitas terlihat pada dosis di atas } \\
62,50 \mu \mathrm{g} / \mathrm{mL}\end{array}$ \\
\hline 4. & Daun Ficus glomerata. & $\begin{array}{l}\text { OECD } \\
236\end{array}$ & $\begin{array}{l}\text { Abusufyan } \quad \text { Shaikh, } \\
\text { Kalidas } \\
\text { Kohale, } \\
\text { Mohammed Ibrahim, } \\
\text { Mohib Khan }\end{array}$ & LC50 sebesar 239,88 ppm \\
\hline 5. & $\begin{array}{l}\text { Momordica charantia } \\
\text { Linn. }\end{array}$ & $\begin{array}{l}\text { OECD } \\
236\end{array}$ & $\begin{array}{l}\text { Siroshini K.Thiagarajan, } \\
\text { Khamini Rama } \\
\text { Krishnan, Thandar Ei, } \\
\text { Nurul Husna Shafie, } \\
\text { DarylJ.Arapoc, } \\
\text { Hasnah Bahari }\end{array}$ & $\begin{array}{l}\text { Nilai LC50 dari hot aqueous Chinese M. } \\
\text { Charantia adalah } 144,54 / \mathrm{g} / \mathrm{ml} \text {. }\end{array}$ \\
\hline 6. & $\begin{array}{l}\text { Ciplukan (Physalis } \\
\text { Minima Linn.) }\end{array}$ & $\begin{array}{l}\text { OECD } \\
414\end{array}$ & $\begin{array}{l}\text { Tuwuh Purnomo, Lucia } \\
\text { Maria Santoso, Riyanto }\end{array}$ & $\begin{array}{l}\text { Memiliki efek teratogenik terhadap fetus } \\
\text { mencit. Dosis minimum yang dapat } \\
\text { rnenyebabkan efek teratogenik yaitu } \\
\text { dosis P1 }(1,4 \mathrm{mgl}\}, 1 \mathrm{ml} \text { Tween } 20110 \mathrm{~g} \mathrm{BB}) \text {. }\end{array}$ \\
\hline 7. & Daun Seledri & $\begin{array}{l}\text { OECD } \\
414\end{array}$ & $\begin{array}{l}\text { Seny Samrotul F., } \\
\text { Muharram Priatna, \& } \\
\text { Yedy Purwandi S. }\end{array}$ & $\begin{array}{l}\text { Infusa daun seledri (Apium graveolens } \\
\text { L.) dosis } 1,2 \text { dan } 3 \text { tidak menimbulkan } \\
\text { efek teratogenik atau malformasi pada } \\
\text { janin, tetapi dosis } 1(0,09 \mathrm{~g} / 200 \mathrm{~g} B \text { B) dan } \\
3(0,36 \mathrm{~g} / 200 \mathrm{~g} \text { BB }) \text { mengakibatkan } \\
\text { peningkatan kematian pada janin secara } \\
\text { signifikan }\end{array}$ \\
\hline 8. & 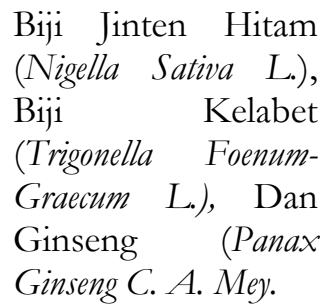 & $\begin{array}{l}\text { OECD } \\
414\end{array}$ & $\begin{array}{l}\text { Fransiska } \\
\text { Christianty, } \\
\text { Winarti }\end{array}$ & Tidak toksik \\
\hline 9. & $\begin{array}{l}\text { Daun Mindi (Melia } \\
\text { Azedarach L) }\end{array}$ & $\begin{array}{l}\text { OECD } \\
414\end{array}$ & $\begin{array}{l}\text { Adisti Erlina sutomo, } \\
\text { Trully D Sitorus, Adhi } \\
\text { Pribadi }\end{array}$ & $\begin{array}{l}\text { Pemberian ekstrak pada dosis } 3,22 \\
\text { mg/kg bb sudah menyebabkan toksisitas } \\
\text { teratogenik }\end{array}$ \\
\hline
\end{tabular}


DOI : https://doi.org/10.24843/JFU.2020.v09.i01.p05

pISSN: 2301-7716; eISSN: 2622-4607

Jurnal Farmasi Udayana, Vol 9, No 1, Tahun 2020, 31-36

\section{DAFTAR PUSTAKA}

Abusufyan,Shaikh., Kalidas, Kohale., Mohammed, Ibrahim., Mohib, Khan. 2019. Teratogenic effects of aqueous extract of Ficus glomerata leaf during embryonic development in zebrafish (Danio rerio). Journal of Applied Pharmaceutical Science Vol. 9(05), pp 107111

Adisti.,Erlina Sutomo, Trully D Sitorus, Adhi Pribadi. 2015. The Teratogenic Effect of The Mindi (Melia azedarach L) Leaves Ethanol Extract on Mice (Mus musculus) Fetus. Althea Medical Journal. 2015;2(2)

Akinola, A., Kok-SongLai., Ahmad, Syahida., Maziah,Mahmood., Noor,Azmi. 2019. Phytochemical Evaluation, Embryotoxicity, and Teratogenic Effects of Curcuma longa Extract on Zebrafish (Danio rerio). Hindawi Evidence-Based Complementary and Alternative Medicine Volume 2019

BPOM.2014. Peraturan Kepala Badan POM No. 12 tahun 2014.

Fransiska Maria Christianty, Lina Winarti. 2012. Uji Teratogenik Campuran Serbuk Biji Jinten Hitam (Nigella Sativa L.), Biji Kelabet (Trigonella Foenum-Graecum L.), Dan Ginseng (Panax Ginseng C. A. Mey.) Pada Tikus Putih Galur Wistar. Stomatognatic (J. K. G Unej) Vol. 9 No. 3 2012: 155-161

Lu E. Teh1, Chin Siang Kue1, Chean Hui Ng, Beng Fye Lau. 2019 .Toxicity Effect of Bougainvillea glabra (Paper Flower) Water Extracts on Zebrafish Embryo. INNOSC
Theranostics and Pharmacological Sciences, 2019, Vol. 2, No. 1

OECD 236. 2013. Fish Embryo Acute Toxicity (FET) Test

OECD 414. 2018. Prenatal Developmental Toxicity Study

Rifngatun Nadhiroh., Diah Andriana., Yudi Purnomo. 2018. Efek Teratogenik Dekokta Daun Pulutan (Urena lobata L.) [Studi terhadap Malformasi Somite dan Non Detachment Tail pada Embrio Ikan Zebra (Danio rerio)]

Seny,Samrotul F., Muharram Priatna., Yedy Purwandi S. 2015. Uji Teratogenisitas Infusa Daun Seledri Pada Tikus Betina Galur Wistar.

Siroshini K.Thiagarajan., Khamini,Rama., ThandarEi., Nurul Husna., Daryl,J.Arapoc., Hasnah,Bahari. 2019. Evaluation of the Effect of Aqueous Momordica charantia Linn. Extract on Zebrafish Embryo Model through Acute Toxicity Assay Assessment. Hindawi Evidence-Based Complementary and Alternative Medicine Volume 2019

Tuwuh Purnomo, Lucia Maria Santoso, Riyanto. 2016. Efek Teratogenik Ekstrak Ciplukan (Physalis Minima Linn.) Terttadap Fetus Mencit (Xius Musculas) Galur Sub Swiss Webster. Jurnal Pembelajaran Biologi, Vol.3 teratogenik. https://id.scribd.com/doc/302619787/PP T-Uji-Toksisitas-Khas-Teratogenik-Fix tanggal 19-12-19 